\title{
Covid-19 Infection Experience of a Family Phycisian in Turkey
}

\section{Türkiye'de Bir Aile Hekiminin Covid-19 Enfeksiyonu Deneyimi}

\author{
Nil Tekin ${ }^{* 1}$
}

\begin{abstract}
Coronavirus Diesease 2019 (COVID-19), which was first seen in China in December 2019 and spread all over the world, has been reported to cause retention of the lower respiratory tract and cause acute respiratory distress syndrome. The first case was reported on 11 March 2020 in Turkey, WHO declared a pandemic on the same day A great struggle has started with the pandemic all over the world. Healthcare workers struggle at the forefront. In this article, the illness experience of a Turkish family physcian who had the infection is shared.
\end{abstract}

Key words: Covid-19, pandemic, family phycisian

ÖZET

Aralık 2019'da Çin'de ilk kez görülen ve tüm dünyaya yayılan Koronavirüs 2019 Hastalığı (COVID-19)'un, alt solunum yollarının tutulmasına neden olduğu ve akut solunum yetmezliği sendromuna yol açttğı bildirilmiştir. Türkiye'de ilk olgu 11 Mart 2020 tarihinde bildirilmiş, aynı gün DSÖ pandemi ilan etmiştir. Bütün dünyada pandemi ile büyük bir mücadele başlatılmıştır. Sağlık çalışanları en önde mücadele etmektedir. Bu yazıda enfeksiyonu geçiren bir aile hekiminin hastalık deneyimi paylaşılmıştır.

Anahtar kelimeler: Covid-19, pandemi, aile hekimi

Received date / Geliş tarihi: 03.05.2020, Accepted date / Kabul tarihi: 05.05.2020

${ }^{11}$ AÇSHB Narlıdere Huzurevi Yaşlı Bakım ve Rehabilitasyon Merkezi, Izmir-TURKEY.

*Address for Correspondence / Yazışma Adresi: Nil Tekin, AÇSHB Narlıdere Huzurevi Yaşlı Bakım ve Rehabilitasyon Merkezi, Izmir

TURKEY.

E-mail: niltekin33@yahoo.com

Tekin N. Covid-19 Infection Experience of a Family Phycisian in Turkey. TJFMPC, 2020;14(2): 166-170.

DOI: $10.21763 /$ tjfmpc.731521 


\section{COVID-19 INFECTION EXPERIENCE OF A FAMILY PHYCISIAN IN TURKEY}

In the memory of all healthcare professionals who struggled with COVID-19 and we lost, so that people could live, like the Chinese Dr. Li Wenliang, who announced the first cases to the world and like Prof. Dr. Cemil Taşçloğlu who cared for the first patients in our country. THANKFULLY, RESPECTFULLY.

\section{Letter to The Editor,}

As a family physician who has had COVID-19 infection working in a nursing home, in Turkey. I think it is important to share my experience including risk factors, diagnosis and treatment applications of this infection.

\section{COVID-19 and Pandemic}

In Wuhan Province, China, in December 2019, the new Coronavirus 2019 (COVID-19) was reported to involve the lower respiratory tract causing acute respiratory distress (ARDS) syndrome. COVID-19 causative virus (SARS-CoV-2) has launched a lifethreatening epidemic worldwide. The first case was reported in Turkey on March 11, at 20:20, the same day the World Health Organization declared COVID-19 as a pandemic. ${ }^{1,2}$

SARS-CoV-2, a family member of beta coronaviruses, has an envelope which are responsible for viral infectivity, membrane, nucleocapsid, structural proteins, and one-way positive polarity RNA. Coronaviruses have the largest genomes among all RNA viruses. The spikes on the surface give a crown (corona)-like appearance under the electron microscope. Coronavirus is called because its spikes on the surface lead to the appearance of the crown. ${ }^{1,3,4}$

The coronavirus has ruled the world's agenda almost alone for the past five months. In May 2020, it is seen that there were approximately 3.5 million diagnosed cases and 250,000 deaths in this pandemic. It has been observed that $16 \%$ of cases diagnosed in the USA are healthcare workers. In Turkey, this rate of $6 \%(n=7428)$ is described. It is a known fact that thousands of healthcare workers have lost their lives due to COVID-19 infection despite all protection and precautions in the world. ${ }^{5-}$

\section{Isolation and Contact:}

I work in the highest-capacity nursing home in our country. ${ }^{8}$ I'm a 50 -year-old female family doctor with no chronic disease. Following the first cases reported in Turkey, over the next two weeks I've just been between home and work and have no social activities. For the next 3 weeks, I was staying at work for the isolation establishment and provision of full-time service with special clothing and equipment, following all the protection measures (Picture1).

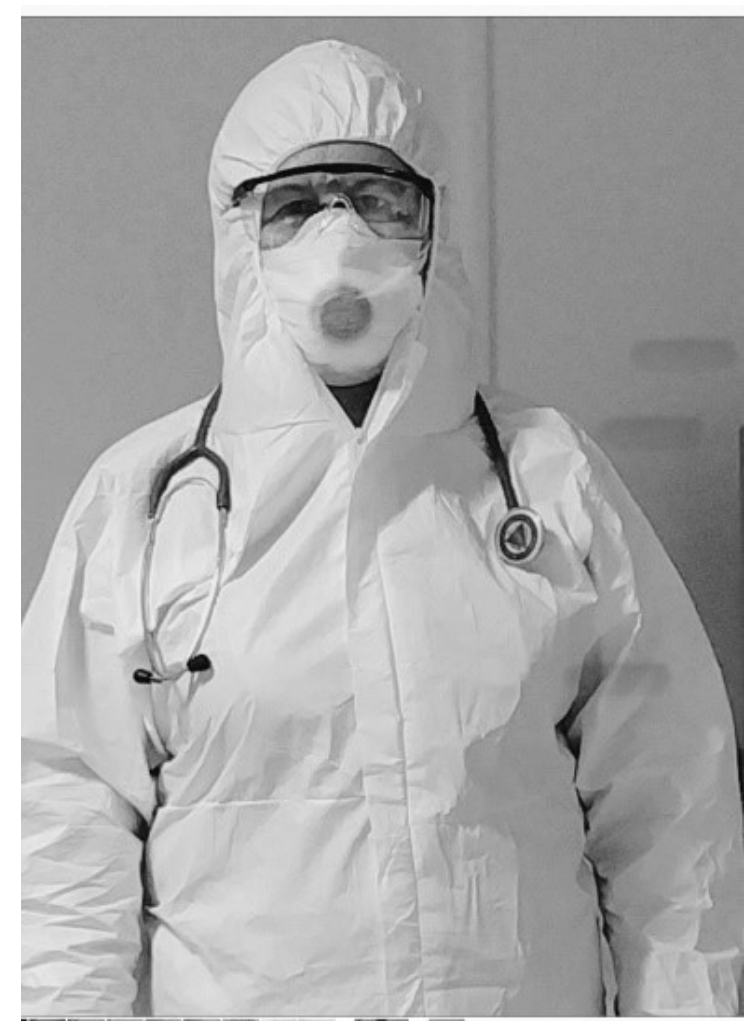
Picture 1. Special clothing and equipment for
COVID-19

Although strict measures were taken in nursing homes during the COVID-19 control process, cases were seen but their spread was prevented. ${ }^{9}$ In this process, regular tests were applied to the staff and residents in the nursing home. The PCR test I had at the beginning of the isolation was negative. I had multiple intense contact stories that were protected due to examinations of suspicious cases, referrals to hospital, discharge from hospital and cardiopulmonary resuscitation (CPR) applications.

\section{Encounter of COVID-19:}

a) Beginning: I had complaints of weakness, loss of appetite, inability to taste, nausea, mild diarrhea and an increasingly frequent sputum cough that had been ongoing for the last 3 days. There was no fever and respiratory distress. On the 3rd day of my complaints, I applied to the pandemic emergency clinic for further examination and treatment, as the routine PCR test was positive. 
1st Day Blood Tests: WBC, Lymphocyte, Hemogram, CRP, blood glucose test, liver, and kidney function tests, electrolytes, CKMB, platelet count, troponin level, procalcitonin, aPTT and ferritin were normal. DDIMER $0.6 \mu \mathrm{g} / \mathrm{mL}(0$ 0.55). LDH $250.00 \mathrm{U} / \mathrm{L}$ (125 - 220) was detected. In Thorax CT performed without the use of intravenous contrast agent on the application date; In terms of COVID evaluation, the prevalence of ground glass opacity in bilateral basal was to cover $1 / 3$ of the peripheral areas in the lower lobes. Emphysema and fibrosis were not observed. Conclusion: Typical / Possible COVID-19 infection was evaluated as compatible radiological findings (Picture 2).

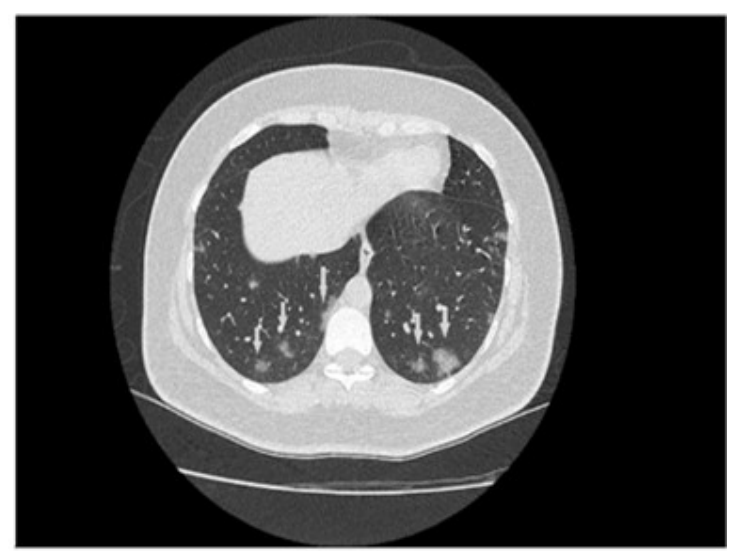

Picture 2. Thorax CT bilateral glass opacity at lower zones

During the examination, the need for intermittent deep breathing started during the examinations. However, the respiratory rate was $20 / \mathrm{min}$ and $\mathrm{O}_{2}$ saturation was $98 \%$. Monitoring at home voluntarily, and consultation decision was made twice a day with Emergency Medicine and Infectious Diseases specialists. In accordance with the guideline (Update: April 14, 2020) of Turkish Ministry of Health COVID-19 (SARS-CoV-2), Hydroxychloroquine (HCQ) was planned as $2 \times 400$ $\mathrm{mg}$ on the first day, then $2 \times 200 \mathrm{mg}$ for 5 days and Fraxiparin $0.4 \mathrm{mg}$ sc for 7 days. ${ }^{10}$ In case of close follow-up of saturation with a pulse oximeter, presence of shortness of breath, fever, and tachypnea, referring to an emergency pandemic outpatient clinic was requested. I was discharged by signing a form for absolute home isolation.

I first experienced some confusion and difficulty in accepting lung involvement in encountering COVID-19 infection. From the day I was diagnosed, I started to receive support from the clinical psychologist over the phone. b) $5^{\text {th }}$ day: From the second day of treatment, weakness and appetite improved. Since the 5th day, gastrointestinal symptoms completely resolved, and my anxiety decreased.

$5^{\text {th }}$ day Blood Test: Hemogram, CRP, liver and kidney function tests, and electrolytes were normal. Despite gradually decreasing air hunger in deep sighing style for a week, saturation did not fall below $98 \%$.

During this period, telephone consultations with consultant physicians continued daily. My family physician also continued to follow up on the phone for symptom control daily.

c) 14th day: There were no symptoms except for intermittent cough. I applied to the pandemic outpatient clinic for control. WBC, Lymphocyte, Hemogram, CRP, blood glucose test, liver and kidney function tests were normal. In the thorax CT, infiltration areas (in the bilateral middle and lower ground glass opacities with patchy consolidation, and peripherally located ground-glass opacity) were significantly reduced and faded. No new infiltration or consolidation was detected. The PCR test was negative.

\section{COVID- 19: Symptoms, Findings and Treatment}

Fever, dry cough and progressive dyspnea are common symptoms in patients infected with COVID-19. After an average incubation period of about 5 days (range: 2-14 days), a typical COVID19 infection begins with dry cough and low-grade fever $\left(38.1-39^{\circ} \mathrm{C}\right)$, often accompanied by a decrease in smell and taste. It is argued that different symptoms may be seen recently. At a later stage, patients may experience shortness of breath and require mechanical ventilation. ${ }^{11}$

According to the progression of the disease, it is grouped as asymptomatic cases followed by outpatient hospitalization, mild cases followed by hospitalization, serious cases with many organ failures requiring intensive care unit applications (about 15\%). ${ }^{1,10,11}$ It has been suggested that during the response to SARS-CoV-2, immune regulation disorder and high levels of proinflammatory cytokines may be the main cause of tissue damage. However, the exact pathophysiological mechanism of COVID-19 is still largely unknown. ${ }^{1}$

In possible/definitive COVID-19 cases, thorax CT is used to support diagnosis, demonstrate lung involvement or evaluate the extent of infection in the lung. In this current pandemic, it was clearly seen that very early subclinical patients may have pathological CT findings. Pathological images often show bilateral involvement in the lower lobes, and 
multiple, patchy, or ground-glass opacities with subpleural distribution in the bilateral lobes. However, CT findings are common, including consolidation, greater lung involvement, linear opacities, the "crazy-paving" pattern, and the "reverse halo" sign longer after the onset of symptoms. 1,10,11 Thorax CT images when I arrived at the hospital were compatible with the literature.

Effective host immune response, including natural and acquired immunity to SARS-Cov-2, is essential to control and resolve the viral infection. However, the severity and outcome of COVID-19 may be associated with overproduction of the proinflammatory cytokines "cytokine storm" of leading to acute respiratory distress syndrome. Unfortunately, the exact pathophysiology and treatment are still uncertain, especially for severe COVID-19. Currently, there is no specific treatment for COVID-19 has been proven to be safe and effective. HCQ used in treatment blocks the virusreceptor binding and virus-endosome fusion. ${ }^{1,10}$

The development of thromboembolic events with various mechanisms in the course of COVID19 is remarkable. Since death is more frequently observed in patients who develop coagulopathy, its monitoring should be initiated with a diagnosis. Therefore, as soon as the diagnosis is made, coagulopathy monitoring should be started. Thrombosis heparin prophylaxis (Enoxaparin 40 $\mathrm{mg}$ /day $1 \mathrm{x} 1 \mathrm{sc}$ ) was applied to all COVID-19 patients in accordance with guidelines (Update: April 14, 2020) of Turkish Ministry of Health's COVID-19 (SARS-CoV-2). ${ }^{10}$

\section{Evaluation of the COVID-19 Experience:}

* At the South Korean border gate, we came to for the WONCA 2018 World Congress, fever was measured with special cloths, masks, visors; and our medical history was taken. I have now better understanding: the practice is the result of a country's experience.

* Prevention is the most important method, but intensive contact risks such as CPR require attention even in protected contact. ${ }^{7,12}$

* Among the symptoms of COVID-19, fever, which is very important, may not always be.

* COVID-19 also carries risks for the adult age group without comorbidity. Virus load should be discussed more.

* It is a very important effective filiations practice and to have regular PCR tests in suspicious contact, especially in nursing homes.

* False negatives may be seen in the PCR test, but the positive result is deterministic and rapid diagnosis.
* In early diagnosis, treatment, and follow-up, pulse oximetry can be applied effectively and easily at home.

* It is very important to monitor health professionals over the phone, to get fast health services when there is a problem, and to remotely psychological and social support. Telephone and internet consultations will become increasingly important. ${ }^{2}$

* Effective primary care, continuous updating of the treatment protocol, and its widespread appropriate use are important.

* Early diagnosis and treatment reduces hospitalizations, need for intensive care and deaths.

* All over the world, the medical discipline has the experience of recognizing a new disease, producing and sharing very fast scientific studies in approach and treatment.

* Currently, there is no specific treatment for COVID-19 that has proven safety and efficacy. On the other hand, HCQ treatment with data indicating that it may be effective, albeit limited, is recommended to start immediately in patients who are symptomatic and are considered to have the possibility of COVID-19. ${ }^{10}$

* While doing my family medicine thesis, I listened to the story of the quinine that Dr. Ahmet Y1ldirım used to fight malaria in Nazilli between 19361946. ${ }^{12}$ I experienced HCQ, a synthetic derivative of quinine, in 2020 as a patient in the COVID-19 pandemic. In this process, where I gained my health, I understood the historical experiences and success stories of physicians in our country better.

* The world has witnessed and continues to struggle against COVID-19 by endangering the lives of all physicians and healthcare professionals working in pandemic clinics, primary care, and nursing homes, from a Chinese ophthalmologist to a Turkish family physician.

"It is clear that the winner of this struggle will be science, medicine and ultimately humanity."

\section{REFERENCES}

1. Tufan A, Güler AA, Matucci-Cerinic $M$. COVID-19, immune system response, hyperinflammation and repurposing antirheumatic drugs. Turk J Med Sci 2020; 50: 620-632 doi:10.3906/sag-2004-168.

2. Chauhan V, Galwankar S, Arquilla B, Garg M, Somma SD, El-Menyar A, et al. Novel coronavirus (COVID-19): leveraging telemedicine to optimize care while minimizing exposures and viral transmission. J Emerg Trauma Shock 2020;13:20-4.

3. Masters PS. The Molecular biology of Coronaviruses. Advances in Virus Research 2006, 66:193-292. https://doi.org/10.1016/S0065-3527(06)660053. 
4. Burrell C, Howard C, Murphy F. Coronaviruses. In: Fenner and White's Medical Virology. 5th ed. Elsevier's Academic Press: 2016: p.437-46.

5. WHO. Coronavirus disease (COVID-19) outbreak situation. https:/www.who.int/emergencies/diseases/ novel-coronavirus-2019 adresinden 01.05.2020 tarihinde erişilmiştir.

6. CDC COVID-19 Response Team. Characteristics of Health Care Personnel with COVID-19 - United States, February 12April 9, 2020. MMWR Morb Mortal Wkly Rep 2020;69:477-481. DOI: http://dx.doi.org/10.15585/mmwr.mm6915e6e xternal icon

7. https://www.medimagazin.com.tr/guncel/genel /tr-saglik-bakani-fahrettin-koca-enfekte-olan7428-saglik-calisanimiz-var-11-68188528.html adresinden 01.05.2020 tarihinde erişilmiştir.

8. Tekin, N., Dişçigil, G.A Novel model of comprehensive geriatric care center in Turkey. Middle East Journal of Age and Aging 2007; 4(1): 24-25.

9. https://www.trthaber.com/haber/koronavirus/k oronavirus-vakasi-saptanan-huzurevlerindeyayilim-onlendi-476448.html 01.05.2020 tarihinde erişilmiştir

10. Bilim Kurulu Çalışması. Sağlık Bakanlığı Tanı Tedavi Rehberi. https://covid19bilgi.saglik.gov.tr /depo/rehberler/COVID-19_Rehberi.pdf adresinden 24.04.2020 tarihinde erişilmiştir.

11. Kamps BS, Hoffmann C. COVID Reference. Edition 2020 3. Steinhäuser Verlag www.CovidReference.com adresinden 25.04.2020 tarihinde erişilmiştir.

12. Tekin N, Başak O. İstanbul Tıp Fakültesi ilk mezunlarından bir Aydın'li: Dr. Ahmet Yıldırım", Türkiye Klinikleri Tıp EtiğiHukuku-Tarihi Dergisi; 2008; 16(2): 69-73.

Acknowledgments: I would like to thank Prof Vildan Avkan Oğuz, Assoc. Prof. Başak Bayram, Prof. Mehtap Kartal, Prof. Dilek Güldal, Prof. Nilgün Özçakar and Prof. Gülay Dirik for the diagnosis and treatment process in my fight against COVID-19. I would also like to thank all the working health and care workers, my loyal colleagues and managers. 